${ }^{2}$ Warsaw University of Life Sciences - SGGW

\title{
Geographical Indications and Traditional Specialities: Case Study of Poland
}

\begin{abstract}
The contemporary development of rural areas requires verified agricultural production and support for manufacturing of traditional and regional high-quality products. The aim of the research described in this article has been to assess customer awareness of these products and to identify the features attributed to them in view of existing legal regulations. A catalogue of currently binding regulations has been established, taking account of their axiological assumptions, and results of a survey have been analysed. An assessment of the law functioning in this area has allowed the conclusion that a simplification of the existing regulations and procedures is needed. This is the precondition for the axiological assumptions of the said regulations to be fulfilled. The weight of the discussed subject has been proven by the results of the conducted survey: $93 \%$ of the respondents declared buying the described products. The quality of the products, as well as the respondents' pride in the indigenous culinary tradition, were the main reason for their choice (54\%). Examining the laws in the discussed area requires adoption of an interdisciplinary axiological perspective.
\end{abstract}

Key words: geographical indications, traditional and regional products, intellectual property, visual communication

JEL Classification: L15

\section{Introduction}

Interest is growing among foods consumers and producers alike in high quality regional and traditional products. Meanwhile, the EU member states are highlighting the need to preserve diversity of agricultural production. The quality and diversity of the EU agricultural production are one of its important assets, giving a competitive advantage to the producers and contributing to the maintenance of vivid cultural and culinary heritage. In this context, the European and national legal protection systems are an important tool for the development of competitiveness of the European Economic Area (EEA) on the global agricultural and food products market.

In view of the above, the research described in this article has concentrated on the customers' awareness of traditional and regional products and their labelling, taking special account of the normative acts binding in this area.

The main purpose of this study was to assess customer awareness of these products and to identify the features attributed to them in view of the existing legal regulations. We conducted a critical review of the currently binding legal regulations and of the social and

\footnotetext{
${ }^{1}$ PhD., Faculty of Low and Administration, University of Szczecin, ul. Narutowicza 17a, 70-240 Szczecin, e-mail: inga.oleksiuk@usz.edu.pl,https://orcid.org/0000-0003-2682-8968

${ }^{2} \mathrm{PhD}$., Faculty of Economic Sciences, Warsaw University of Life Sciences, ul. Nowoursynowska 166, 02-787-Warszawa, e-mail: agnieszka_werenowska@sggw.pl,https://orcid.org/0000-0002-2545-4442
} 
economic realities related to their implementation. We attempted to answer the following questions:

- are traditional and regional products a matter of interest for the surveyed customers?

- what are the main reasons for the purchase of the above described products?

- are the sense of pride and the culinary traditions of any significance for the choice of food products?

- what are the axiological assumptions, characteristics and instruments of the regional and traditional products protection?

- are the features of regional and traditional products specified in the EU legislature in line with to those indicated by the surveyed population?

An interdisciplinary methodological approach was also offered.

\section{Regional and traditional products in the EU legislation}

The development of legal regulations pertaining to the labelling of traditional and regional foods has a global dimension but the existing regulations are significantly varied. A stark example of this variety is provided by the solutions adopted in the European Union and in the United States. The differences in the above-mentioned systems are fundamental in nature and result from various axiological assumptions. In the United States, protection of names used to designate traditional or regional products is basically maintained by means of trademarks, and in the European Union a complicated system of national and supranational regulations has been developed in which interests of producers of the said products are protected by means of sui generi legal instruments. The catalogue of indications used for this purpose includes in particular, geographical names, names of origin and regional names. The aforementioned do not preclude the possibility of obtaining legal protection in the form of a trademark ${ }^{3}$.

In the light of the law binding in the EU and in Poland, protected geographical indications are applied to products related to a geographical area, the name of which the indications refer to. The basic normative acts in this area are: Regulation $(E U)$ No 1151/2012 of the European Parliament and of the Council on quality schemes for agricultural products and foodstuffs; Commission Delegated Regulation (EU) No 664/2014 of 18 December 2013 supplementing Regulation (EU) No 1151/2012 of the European Parliament and of the Council, with regard to the establishment of the Union symbols for protected designations of origin, protected geographical indications and traditional specialities guaranteed, as well as with regard to certain rules on sourcing, certain procedural rules and certain additional transitional rules (OJ EU L 179, 2014).

Defining the notion of the geographical indication, it is worth noting that this is an intangible asset, the medium of which is a designation related to a specific geographical area. This points out to the symbolic character of the geographical indication, the intangible value of which is related to the fact that the consumer receives information regarding features and qualities of a specific product, and he gives a positive meaning to the received

\footnotetext{
${ }^{3}$ See: Regulation (EU) No 1151/2012 of the European Parliament and of the Council on quality schemes for agricultural products and foodstuffs. The motivations behind the legal acts and their catalogue are quoted in the preamble to the above mentioned act.

${ }^{4}$ OJ EU L 179 from 19.6.2014, p. 17.
} 
message. This message evokes positive feelings, associations and assessments (a positive connotation $^{5}$ ). The use of geographical indications as a form of promotion of regional products requires sufficient cultural competence and legal awareness on the part of the receivers. At the same time, it is conductive to strengthening of the community, as well as to raising the awareness of the customs and traditions. In this context it is worth signalling that the research of the awareness of regional and traditional products with regard to geographical indications tends to suggest that the average Polish receiver of commercial messages recognises only a narrow catalogue of basic products.

Analysing Polish legal regulations, it is worth noticing that only those indications are subject to protection which cumulatively meet the following conditions ${ }^{6}$ :

1. They identify the product as coming from a specific geographical area, which needs to be understood as signifying that at least one stage of the product's manufacturing needs to take place in the area.

2. The product is distinguished by its quality, good opinion or other specific features.

3. The feature which distinguishes a product from other goods similar in kind (Point 2) is associated by the customer with an area indicated in Point 1.

In the context of this analysis the notion of traditional products needs to be explained in more detail. According to the [Polish] Act of December 17, 2004 on registration and protection of names and designations of agricultural products and foodstuffs as well as traditional products, traditional products are those whose quality or specific features of which result from the use of traditional modes of production. These modes are transmitted from one generation to another and form a part of the cultural heritage of the region in which they are manufactured. The products' relation to the sense of identity of the local community is another important aspect (Article 47.1 of the said Polish Act). To obtain legal protection, an entry onto the list of traditional products is required. As of 19.06.2018 the current list includes 1172 entries $^{7}$.

Under Regulation (EU) No 1151/2012 of the European Parliament and of the Council of 21 November 2012 on quality schemes for agricultural products and foodstuffs, ${ }^{8}$ : "A name shall be eligible for registration as a "traditional speciality guaranteed" where it describes a specific product or foodstuff that:

(a) results from a mode of production, processing or composition corresponding to traditional practice for that product or foodstuff; or

(b) is produced from raw materials or ingredients that are those traditionally used. (Art. 18.1)"

\footnotetext{
${ }^{5}$ Compare: Barańczyk, I. (2008). Ochrona prawna oznaczeń geograficznych, Warsaw, passim; Kondrat, M. (2003) Oznaczenia geograficzne we Wspólnej Europie, PPH 2003 No. 12 p. 13; Szczepanowska-Kozłowska, K.(2004). Oznaczenia geograficzne i nazwy pochodzenia w prawie wspólnotowym, PPH, 2004, 11, p. 6-7; Szewc, A., G. Jyż, (2011) Prawo własności przemysłowej, ed.2 C.H.BECK, Warsaw, p. 130.

${ }^{6}$ Polish Industrial Property Law as amended by act of 23 January 2004 and act of 29 June 2007, (Journal of Laws of 2017 r., item 776); Act of 16 April 1993 on combating unfair competition (Journal of Laws No 03.153.1503,.2003.11.28 amend), Act of December 17, 2004 on registration and protection of names and designations of agricultural products and foodstuffs as well as traditional products (Journal of Laws No. 171 of 2017, item 1168).

${ }^{7}$ https://www.gov.pl/rolnictwo/lista-produktow-tradycyjnych12 [dostęp: 16.07.2018].

${ }^{8}$ OJ L 343, 14.12.2012, p. 1-29, EUR-Lex - 32012R1151 - EN, CELEX:32012R1151, https://eur-lex.europa.eu /legal-content/ PL/TXT/HTML/?uri=CELEX:32012R1151\&from=pl.
} 
Under the said Regulation (Article 3 (3)), "'traditional' means proven usage on the domestic market for a period that allows transmission between generations; this period is to be at least 30 years"'.

For protection of traditional products, the European Certification System (ECS) uses three main symbols: "Protected Designation of Origin" (PDO), "Protected Geographical Indication" (PGI) and "Traditional Speciality Guaranteed" (TSG). The goodwill associated with these symbols is based on consumer trust, and the symbols' reliability is subject to verification and controls. The use of such labelling is needed to gain unequivocal and clear identification by prospective customers who, thereby, have a chance to identify a specific group of products more easily. It is important to work towards a situation in which the awareness of the existence and the recognisability of the symbols will be high.

\section{Axiological assumptions and goals of legal protection}

A geographical indication is an intellectual property protected by law on the national, regional and international levels. In this context it is worth noticing that the reasons (ratio legis) justifying legislation with reference to the laws specifying the use of this asset encompass many aspects: economic, social and cultural, public, individual, group, regional and national ones. Together, they form a complex and coherent system of regulations. In the literature on the subject of public economic law it is highlighted that respect for private intellectual property (Kohutek, Sieradzka, 2014; Oleksiuk, 2015) in long terms leads to technological and economic development. This is one of the motives behind its protection and in this scope it is coherent with ratio legis of the Polish national regulation on geographical indications. The convergence of these goals is also reflected in the Preamble to the above quoted Regulation No. 1151/2012 of the European Parliament and the Council, and is in line with the long-term EU strategy of economic development, the goal of which is to transform the European Economic Area (EEA) into "the most competitive, knowledge-based economy, capable of achieving sustainable economic growth through a greater number of better employment and more social coherence" (the Lisbon Target). Pursuing of the goals set at the beginning of this century does not only mean adjusting laws to the ongoing changes but it also requires developing new regulations conductive to implementing of innovations and R\&D cooperation projects and, at the same time, supporting small and medium enterprises on the home market of agricultural production. This is why in the highly developed countries the law of intellectual property has become a priority area of legislative works ${ }^{10}$. Similarly, in the countries where citizens are beginning to determine the direction of changes of the global knowledge-based economy, establishment of a rational and axiologically coherent system for the protection of innovations is deemed a sine qua non premise for the development of civilisational.

A justification for the limiting of economic freedom on the market of agricultural and traditional products is provided by the claim that the general social and economic benefits

\footnotetext{
${ }^{9}$ Ibidem.

${ }^{10}$ The rationale behind formulating these goals was the awareness of the huge advantage held by the United States. This advantage stemmed from the high R\&D expenditures, exceeding those of the European Union by around 12 billion dollars, and the skilful use of technological innovations for commercial purposes. See: Gradziuk, A., Skubiszewska J., Posiedzenie Rady Europejskiej w Brukseli, 20-21 March 2003, „Biuletyn” (PISM), No. 18 (122) from 24 March 2003.
} 
resulting from the guarantee of exclusiveness on manufacturing certain products granted to specific entities, in the long-term perspective largely exceeds its impact on the free competition $^{11}$.

A distinguishing characteristic of Continental Europe's legal order is that the goal of legal protection of intellectual property, among others involving regulations pertaining to the labelling of regional and traditional products, is not limited to protection of economic interests of producers or distributors of these products. These issues were raised by the European Court of Justice (ECJ) in the decision of 24.01.1989. The ECJ noted that the general interest vested in protection of intellectual property has more than just an economic dimension. The development of cultural heritage of EU countries and regions is one of the goals specified in Article 2 of the Treaty on the European Community (TEC) amended by the Treaty on the Functioning of the European Union. Therefore, the functioning of the European Union in this area is the matter of the original acquis communautaire. In view of the provisions of the Treaty, the EU should prioritise those projects which facilitate the advancement of cultures of its individual Member States. Supporting the common cultural heritage is a secondary goal.

In this context Article 167 of the Treaty on the Functioning of the European Union (the former Article 151 TEC) is worth quoting, which obliges the EU authorities to take account of cultural aspects in their work, especially in view to support the cultural diversity. This regards activities taken in compliance with other provisions of the treaty, i.e. also in the scope of the internal market development and protection of competitiveness of agricultural products and foodstuffs.

Moreover, under Article 207 of the Treaty on the Functioning of the European Union (former Art. 133 TEC), "The Council shall also act unanimously for the negotiation and conclusion of agreements:

(a) in the field of trade in cultural (...) services, where these agreements risk prejudicing the Union's cultural and linguistic diversity".

(b) Also crucial are the obligations undertaken by the European Union as a signatory of the Convention on the Protection and Promotion of the Diversity of Cultural Expressions (Journal of Low, 2007) $^{12}$.

It is also important to note the specifics and diversity of agricultural production, and especially regional and traditional products. They are of significance in the process of improving the competitiveness of the sector. They are also subject to legal protection due to their market value, as mediums of identity and cultural assets. High quality of the discussed products offers them an advantage over mass production both home and abroad. Apart from quality, what impacts their competitiveness is undoubtedly their relation to the cultural heritage, nature and - indirectly - to regional development.

The growing accessibility of the products and the rising awareness of their health and flavour properties impacts changes in dietary methods and habits of the customers. As results from the research conducted in April 2017 by the market and marketing research company ARC Rynek i Opinia "The Consumer on the Market of Traditional and Regional Products", for $65 \%$ of those surveyed the flavour properties are the main reason for purchase of said products. Over half of the respondents bought traditional and

\footnotetext{
${ }^{11}$ Kohutek K., comments on Article 2 in: Kohutek, K, Sieradzka, M., supra, p. 75.

${ }^{12}$ Convention on the Protection and Promotion of the Diversity of Cultural Expressions 2005, Paris, 20 October, 2005 (Journal of Laws of 2007 r., Nr 215, item 1585).
} 
regional food with a view to supporting the Polish economy. It is interesting and indicative for a trend in customer behaviour that $49 \%$ of those surveyed bought regional and traditional products in order to make sure that "I know what I eat". Over half (48\%) believed the foodstuffs to be healthier (ARC, Rynek I Opinia 2017). The data and results of research presented further in this article support the claim that the market of traditional and regional products is going to develop.

\section{The method of research}

The pursuit of the research goals has determined the choice of methods. The outlined subject area goes beyond a linguistic analysis of legal regulations. Therefore, it seems reasonable to use tools of teleological and functional analysis. Such an approach is also favoured by the complex, multifaceted character of matters related to the protection of traditional and regional products with the use of legal instruments. An assessment of the functioning of legal regulations and at the same time viewing certain phenomena as a part of the social system requires the use of an external comparative method (contextualism), which draws from the abundant achievements of economic and social sciences. Implementation of the set goal is, therefore, related to picturing the dynamics of economic processes against the background of an analysis of the discussed regulations both from the point of view of the functions they play and the goals they serve in everyday use.

In view of the above, in the course of the studies presented in this article an analysis was conducted of source and secondary materials. The studies also used a diagnostic survey. The factual state was established, revealing relationships between phenomena and processes. A questionnaire survey was conducted for the purposes of this article. The approach was both quantitative and qualitative in nature. The choice of respondents was random. The study was attended by adults only.

The questionnaire survey was conducted from March to June 2018 and participated by 205 persons of Polish citizenship - 139 women and 66 men. Over half $(58 \%)$ of the respondents declared their age as being between 18 and 25. The 25-35 age group accounted for $24 \%$ of the surveyed population. The smallest representation was recorded in the age groups of 36-45 and over 45 years (8\%) each. Most of the respondents lived in cities with over 500 thousand residents (31\%). The second largest group were residents of rural areas (22\%), followed by residents of towns with 50-100 thousand inhabitants (9\%). Most of the respondents $(63 \%)$ declared secondary school education status; the remaining $37 \%$ had higher education.

\section{Results of the studies}

The conducted studies and the analysis of their results have allowed for answering the basic research questions regarding the interest and motives involved in the purchase of traditional and regional products.

A strong majority of the population declared making regular purchases of Polish traditional $(93 \%)$ and regional $(90 \%)$ products. To broaden the study's perspective, the surveyed were also asked about making purchases of the above-mentioned types of products of foreign origin. An analysis of the results indicates more interest in Polish products ranked 
in the "traditional" category (93\%) rather than in foreign ones (70\%). A similar correlation occurred with reference to regional Polish $(90 \%)$ and foreign (66\%) products.

With reference to Polish traditional products women displayed a slightly stronger attachment (64\%). No such difference was observed in the case of regional products. Residents of cities and towns with the populations of 50-100 thousand (100\%) and 100- 500 thousand $(93 \%)$ were the main buyers of both said categories of products. What is also worth noticing is the fact that people over 45 years old declared purchases of traditional products.

Still, the customers behaviour does not correspond to real knowledge of Polish culinary traditions. In this context it is worth noting that the register of traditional products includes 1172 entries. Yet, the responses of the surveyed indicated knowledge of a very limited catalogue of these products, strongly dominated by: sauerkraut-and-meat stew (bigos), dumplings (pierogi), pork chop (schabowy), alcohols and pickles. ${ }^{13}$ Quality was the main reason for buying regional and traditional products (74\%). It is worth noting that the respondents did not associate these products with health properties (15\%). Especially for men the health-related aspect was almost irrelevant $(2 \%)$. This is congruent with the results regarding knowledge of characteristic features of traditional products, according to which only $13 \%$ of the surveyed indicated that these are ecological products. On the other hand, there is a strong correlation between quality and flavour properties $(69 \%)$. The surveyed have more appreciation for the relation between tradition and the sense of pride resulting from it (54\%) than for the possession of certificates and health properties (Figure 1).

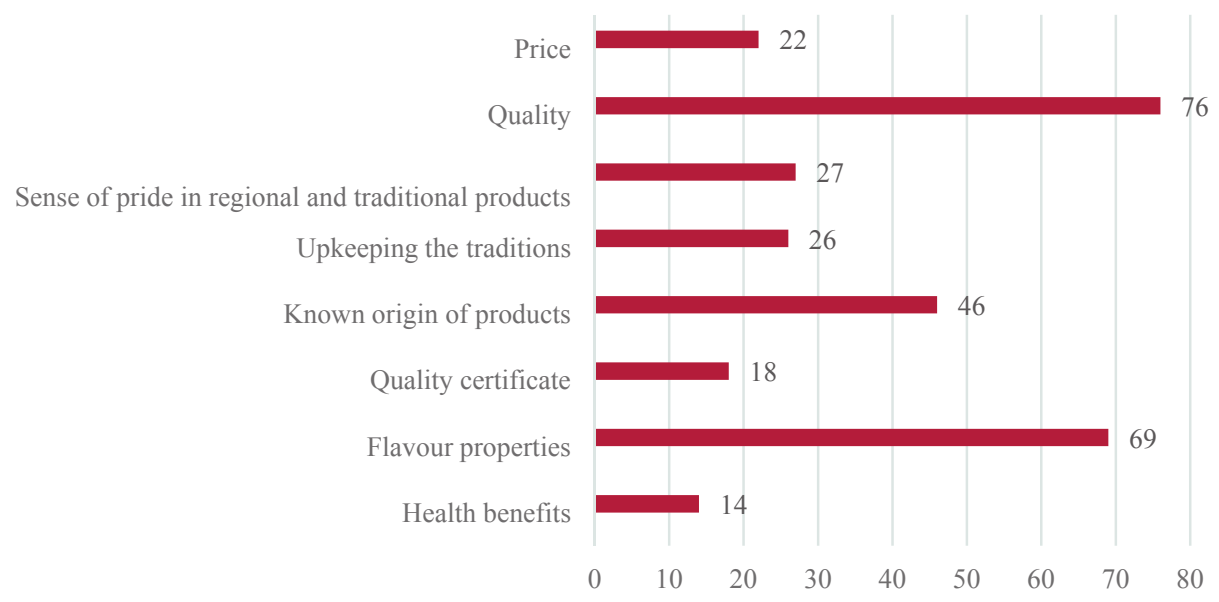

Fig. 1. Reasons for the choice of traditional and regional products [\%]

Source: Authors' own research.

In recognition of the significance of the existing system of geographical indications of the said category of products it was deemed reasonable to probe the respondents' knowledge of the main European and two Polish commonly used indications. The

\footnotetext{
${ }^{13}$ Compare: The Register of Traditional Products held in fulfilment of Article 47 of the Polish Act of 17 December 2004 on registration and protection of names and indications for agricultural products, foodstuffs and traditional products, (Dz. U. Journal of Laws from 2005 No. 10, item 68) https://www.gov.pl/rolnictwo/lista-produktowtradycyjnych12 [accessed: 16.07.2018]
} 
responses obtained in this scope are in line with reasons for the purchase of these products. As many as $76 \%$ of those surveyed recognised the "Quality Tradition" sign which belongs to the national food quality system. The sign may be obtained by all farmers and food producers both in Poland and abroad. Quality is the only criterion for qualification of the products. Another recognisable indication was the European symbol "Traditional Speciality Guaranteed" (37\%). Such a big difference in recognisability is inspiring for further deepened research in this area.

\section{Summary}

The analysis regarded the recognisability of traditional and regional products and the features assigned to them, viewed in the context of legal regulations. This goal was achieved by identifying the catalogue of currently binding legal regulations, taking special account of their axiological premises and analysing the results of the conducted questionnaire survey. An assessment of laws in this area has allowed the conclusion that it is necessary to simplify and mutually align the binding regulations and procedures. These postulates seem indispensable for implementation of axiological premises of the discussed regulations. The lack of a real significance of European regulations in this scope is highlighted by the fact that the respondents pointed out to the Polish trademark ("Quality Tradition" sign) and not to a geographical indication. It should be noted that as far as the goals are concerned, there is a significant alignment between the hierarchy of social and cultural values with the axiological premises of the currently binding regulations. The results concerning the reasons for the choice of regional and traditional products may serve an example to the point. The overwhelming reasons for purchase were the products' quality - equalised with flavour properties - and the pride and attachment to the culinary traditions.

\section{Literature}

Act of 25. August 2006 on food and nutrition safety (Journal of Laws of 2006, No. 171, item 1225). (Poland).

Act of December 17, 2004 on registration and protection of names and designations of agricultural products and foodstuffs as well as traditional products (Journal of Laws No. 171 of 2017, item 1168) Act of 16 April 1993 on combating unfair competition (Journal of Laws No 03.153.1503,.2003.11.28 as amended).

Barańczyk, I. (2008). Ochrona prawna oznaczeń geograficznych (Legal protection of geographical indications). DIFIN, Warsaw.

Chudy, P., Gierałtowska, U. (2013). Produkty tradycyjne i regionalne z perspektywy szczecińskich studentów (Traditional and regional products from the perspective of Szczecin university students). Journal of Agribusiness and Rural Development, 1(27), 45-52.

Convention on the Protection and Promotion of the Diversity of Cultural Expressions 2005, Paris, 20 October, 2005 (Journal of Laws of 2007 r., Nr 215, item 1585).

Council Regulation (EC) No 510/2006 of 20 March 2006 on the protection of geographical indications and designations of origin for agricultural products and foodstuffs, not in force.

Ferrari, M. (2014). Il nesso fra origine geografica e qualità dei prodotti agroalimentari: i diversi modelli di tutela europei e nordamericani (The link between geographical origin and quality of agri-food products: the different European and North American models of protection). Rivista di Diritto Agrario, 93(2), 142-198.

Grunert, K.G. (2005). Food quality and safety: Consumer perception and demand. European Review of Agricultural Economics, 32(3), 369-391.

Grzybowska-Brzezińska, J., Klepacka, J. (2015). Percepcja atrybutów produktu żywności tradycyjnej (Perception of Attributes of the Traditional Food Product). Handel Wewnętrzny, 3(356), 80-89. 
Gualtieri, F., Vaccari, P., Catizzone, B. (2017). La protezione delle indicazioni geografiche: La nozione di evocazione (Protection of geographical indications: The notion of evocation). Rivista di Diritto Alimentare, $11(2), 15-42$.

http://e-chorzow.com/wp-content/uploads/ARC-Konsument-na-rynku- $\% \mathrm{C} 5 \% \mathrm{BCywno} \% \mathrm{C} 5 \% 9 \mathrm{Bci}$-tradycyjnej-iregionalnej-konferencja-2017-06-21.pdf.

https://www.gov.pl/rolnictwo/lista-produktow-tradycyjnych12.

Kohutek, K., Sieradzka, M. (2014). Ustawa o ochronie konkurencji i konsumentów. Komentarz (Act on Competition and Consumer Protection. Commentary), Lex., Wolters Kluwer Polska, Warszawa.

Kondrat, M. (2003). Oznaczenia geograficzne we Wspólnej Europie (Geographical indications in a common Europe). Przeglad Prawa Handlowego, 12, 6-12.

Oleksiuk, I. (2015). Konkurencja a ochrona autorskich dóbr intelektualnych w Unii Europejskiej (Competition and protection of intellectual property rights in the European Union). Środkowoeuropejskie Studia Polityczne, 2, 85-102.

Polish Industrial Property Law as amended by act of 23 January 2004 and act of 29 June 2007. (Journal of Laws of 2017, item 776)

Poźniak-Niedzielska, M. (2004). Oznaczenia geograficzne (Geographical indications). In: Prawo własności przemysłowej. Ed. M. Poźniak-Niedzielska, Warszawa.

Regulation (EU) No 1151/2012 of the European Parliament and of the Council of 21 November 2012 on quality schemes for agricultural products and foodstuffs, OJL 343, 14.12.2012, pp. 1-29, EUR-Lex-32012R1151EN, CELEX:32012R1151.

Serra, R. (2007). Agricultural Counsellor, Delegation of the European Commission to China, Beijing, the European Union policy for high quality agricultural products, in: International symposium on geographical indications jointly organized by the World Intellectual Property Organization (WIPO) and the State Administration for Industry and Commerce (SAIC) of the People's Republic of China Beijing, June 26-28, 2007. WIPO/GEO/BEI/07/8.

Szczepanowska-Kozłowska, K. (2004). Oznaczenie geograficzne i nazwy pochodzenia w prawie wspólnotowym (Geographical indication and designations of origin in Community law). Przeglad Prawa Handlowego, 11, 4-10.

Szewc, A., Jyż, G. (2011). Prawo własności przemysłowej (Industrial property rights). 2nd ed. C.H. Beck.

Szymecka, A. (2005). Włoski system ochrony produktów regionalnych i tradycyjnych (Italian scheme.for the protection of regional nad traditional products). In: O produktach tradycyjnych i regionalnych. Możliwości a polskie realia (On traditional and regional products. Opportunities and the Polsh reality). Ed. M. Gąsiorowski, Fundacja Fundusz Współpracy, Warsaw, 123-156.

Tiberti, E. (2013). Geographical Indications and Trademarks: space for coexistence as an equitable solution. Rivista di Diritto Alimentare, 7(3), 65-71.

Wikło, E. (ed.). (2003). Księga pamiątkowa z okazji 85-lecia ochrony własności przemysłowej w Polsce (Memorial book on the occasion of the 85th anniversary of protection of industrial property in Poland). Urząd Patentowy Rzeczypospolitej Polskie, Warszawa.

\section{For citation:}

Oleksiuk I., Werenowska A. (2018). Geographical Indications and Traditional Specialities: Case Study of Poland. Problems of World Agriculture, 18(3), 229-237; DOI: 10.22630/PRS.2018.18.3.81 